\title{
パブリックオープンスペースの設計コンセプトにみる 人間一環境関係に関する研究
}

PERSON-ENVIRONMENT RELATIONSHIPS IN DESIGN CONCEPT OF PUBLIC-OPEN-SPACE

\author{
小林健 治*, 鈴木 毅**, 舟橋國男***, 木多道宏**, 李 斌**** \\ Kenji KOBA YASHI, Takeshi SUZUKI, Kunio FUNAHASHI, \\ Michihiro KITA and Bin LI
}

\begin{abstract}
This study aims to clarify what designers think of Person-Environment Relationships, for example, mode of being in place, user situation, and design vocabulary on design concept of Public-0pen-Space.

The method is interpretion of contents and classification of thought about Person-Environment Relationships, in 112 articles published from 1971 to 2002 in "SHIN-KENCHIKU", which is one of the most popular architectural journals in Japan.

The result shows that there are: (1) twelve categories for person-environment relationships in design concepts of public open spaces, (2) historical tendency to thought of person-environment relationships,

(3) relation between person-environment relationships on design concepts and design vocabularies.
\end{abstract}

Keywords : Person-Environment Relationship, Public-Open-Space, Design Concept, Urban Design, Place 人間－環境関係，パブリックオープンスペース，設計コンセプト，アーバンデザイン，場所

\section{1. 研究の目的と意義}

人がある場所にどのように居られるか, その時周囲とどのような関 倸性を得られるかは, 空間が提供する最も基本的な価値のひとつであ る. 近年, アメニティ意識の高まりとともに景観やオープンスペース など都市環境は着実に整備されつつあり, 連日多くの人びとで賑わっ ている場所もしばしば見受けられる.

このような状況の中で, 都市環境, とりわけ都市のもつ魅力のひと つであるといわれるパブリックオープンスペースは今後も都市環境の 重要な要素となっていくことが予想されるが, 現在の都市環境開発は 物理的な環境の整備が主であり, さまざまな人びとが特に何も目的が なくただ居られる場所や，人が居る様子自体が都市の魅力を高めてい るような場所 (1) は必ずしも增えておららず，逆に，綺麗に整備されてい るがどこか居心地が悪く，居場所となりにくい場所も少なくないよう に思われる，そこにはさまざまな問題が考えられるが，都市の中のパ ブリックオープンスペースがどうあるべきかというコンセプトの段階 に第一の問題があるのではないか.

これまでもパブリックオープンスペースに関する研究は数多く行わ れている. 例えば芦原 ${ }^{(2)}$ は，西欧の都市空間を事例として，その外部 空間の視覚的特徵から, 空間も含めた広い意味での場所の形態と知覚 の関係を明らかにしている. 積田 ${ }^{(3)}$ はSD 法・因子分析法を適用して,
都市のオープンスペースに対する人間の心理評価構造を抽出, オープ ンスペースの空間構成要素を分解し，心理量と物理量の相関関係を明 らかにしている. 近江ら (1) は公開空地等のオープンスペース以外の都 市の建物や敷地内にある私的なオープンスペースについて, ショッピ ングモール等を事例として, その形態と形成要因について分析し,さ らにその内外の人びとの行為からみた領域形成について論じている. このように, パブリックスペースに関する研究は数多く存在している が, その多くが現象的にその場所の状態, 状況を明らかにするもので あり, 設計者がどのような意図でその場所を計画したかに関する議論 はあまりなされていない。

以上のようなことから, 本研究では, 建築家の言語的活動に着目し た奥山らによる一連の研究 ${ }^{(5)}$ を参考にしつつ, これまであまり扱われ てこなかった, 設計者がパブリックオープンスペースを計画, デザイ ン寸る際のコンセプトに着目し，設計者がその場所に対してどのよう な利用者の行為を意図してきたかをその言説から抽出し, それらの時 代的変遷, 建物用途との関係, そのためにどのようなデザイン手法を 用いてきたかについて分析し，パブリックオープンスペースにおける 人間一環境系に対する新たな知見を得るための第一段階として, 設計 者のパブリックオープンスペースに対する思考を明らかにすることを 目的とする.

\footnotetext{
* 大阪大学大学院工学研究科建築工学専攻

** 大阪大学大学院工学研究科建築工学尃攻 助教授 $\cdot$ 工博

*** 大阪大学大学院工学研究科建築工学専攻 教授. 工博

**** 大阪大学大学院工学研究科建築工学専攻 助手 $\cdot$ 工博
}

Ph. D. Student, Dept. of Architectural Engineering, Graduate School of Engineering, Osaka University, M. Eng.

Assoc. Prof., Dept. of Architectural Engineering, Graduate School of Engineering, Osaka University, Dr. Eng.

Prof., Dept. of Architectural Engineering, Graduate School of Engineering, Osaka University, Dr. Eng.

Assist Prof., Dept. of Architectural Engineering, Graduate School of Engineering, 


\section{2. 研究方法, 研究対象}

本研究では，設計者の意図が明確な形で現れていると思われる，事 例が揭載されたときの記事, 文章（以下，設計コンセプト）に着目し, 研究対象として，建築及び設計者の意図を掲載寸る雑誌の中で主要な 建築誌のひとつと思われる「新建築」誌 ${ }^{(6)}$ とした。

研究対象事例は, 1971 年 ${ }^{(7)}$ から 2002 年の約 30 年間に揭載された事 例のうち, 1. 外部空間であり, 特定の人だけでなく不特定多数の人び との利用を前提としたパブリックスペース（以下，パブリックオープ ンスペース）を有すること，2. 事例掲載記事中の設計者による文章の 中に，その場所に居る人の様子やその場所の利用（以下，人間一環境

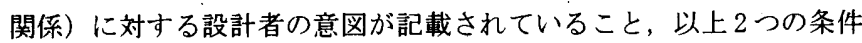
に該当する ${ }^{(8)}$ 事例 112 事例とし，設計者が計画する際に意図していた と思われる設計コンセプト内の人間一環境関係を抽出した。具体的に は，「鳃いの場」，「賑わいを演出」等，その場所に居る人や，周辺環境 に対して何らかの影響を与えるべく意図されているキーワードに注目 し，その場でどのような利用者の行為，活動を想定しているか，ある いは場の質を目標としているかを抽出し，さらにそれらをカテゴリー に分類した ${ }^{(9)}$ (図 1，表 1).

対象事例数は，1970年代が 11 事例であるのに対して，1980年代が 35 事例, 1990 年代が 39 事例と増加の傾向にある。また, 2000 年以降 については 3 年間にも関わらず 27 事例と多くなっている（図 2).

\begin{tabular}{|c|c|c|}
\hline 事例 & \multirow{3}{*}{\multicolumn{2}{|c|}{ 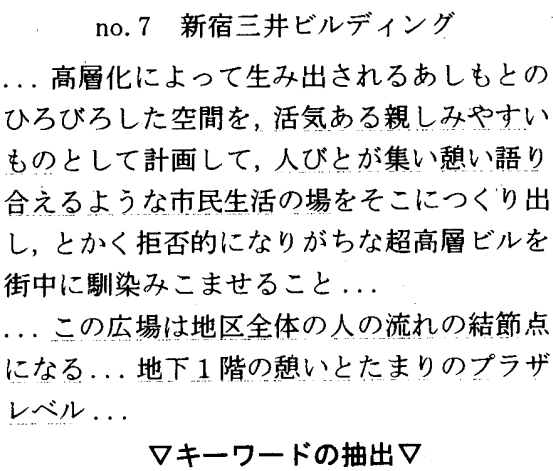 }} \\
\hline $\begin{array}{c}\text { 事例とともにに } \\
\text { 掍載された } \\
\text { 記事, 文章 }\end{array}$ & & \\
\hline \multirow{3}{*}{$\begin{array}{c}\text { 人間一環境関係 } \\
\text { を表す } \\
\text { 「キーワード」 }\end{array}$} & & \\
\hline & \multirow{2}{*}{\multicolumn{2}{|c|}{$\begin{array}{l}\text { 「活気」「集い」「㯘い」「語り合える」 } \\
\text { 「人の流れの結節点」「たまり」 } \\
\nabla K J \text { 法的に分類 } \nabla \\
\end{array}$}} \\
\hline & & \\
\hline \multirow[b]{2}{*}{$\begin{array}{c}\mathrm{KJ} \text { 法的に } \\
\text { 分類された } \\
{[\text { [カゴリー] }}\end{array}$} & キーワード & カテゴリー \\
\hline & 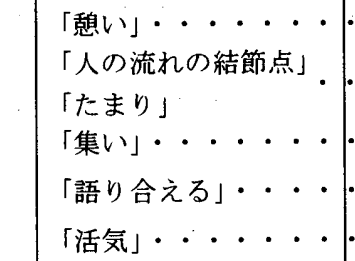 & 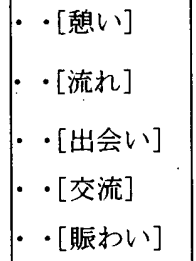 \\
\hline
\end{tabular}

図 $1 \cdot$ 人間一環境関係抽出一分類の例

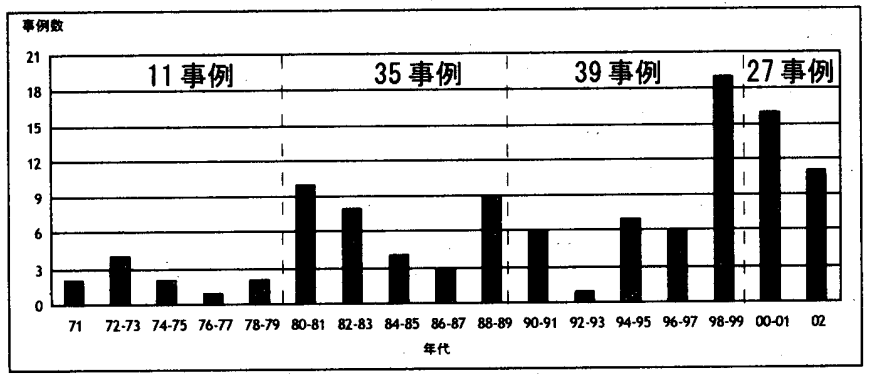

图 2 年別対象事例グラフ
表 1 人間一環境関係カテゴリー分類表とその代表的事例

[安らき] 岁らぎ $/ 5$ 休蒠 $/ 3$ 居心地の良い/2 休む/1 休息/1 レストスベース $/ 1$ 一服の㤼 / 1 俒む/1 くつろぐ/1 リフレッシュ/1

17 月的的な人びとだけでなく通りすがりの人びとにも公阅のベンチのように炎らき を年えまた制激を方えるものにしたいと考えた。

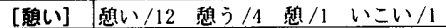

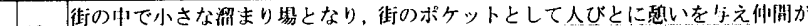
集うスペースとなることを考えました。 通り找け $/ 8$ 通拔け $/ 1$ 通り拔计道 $/ 1$ 通り拔けの道/1 通り找け空間 $/ 2$

[通り抜け了道り拔ける $/ 2$ 通り拔けている/1 近り拔けられる $/ 2$ 近道/3 拔け $/ 1$ 拔けられる/1 步き拔ける/1 横切っていける/1 贯通通路 /

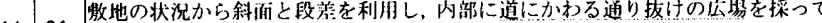
各施設の機能の連絈と分散を試みたのである.

[散策

四遊 $/ 5$ 回遊性 $/ 4$ 回遊路/1 们遊式ショッピング近路/1 国遊式庭湖/

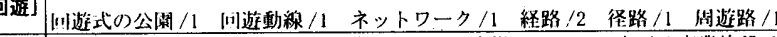

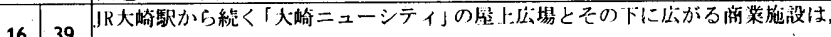

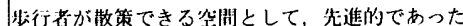

(no. 77)

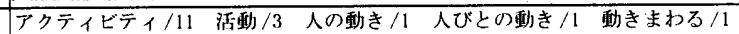

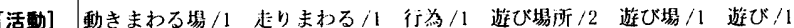

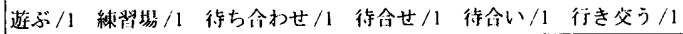

1730 サンクンガーデンは, 地下1階に位略しているが域内でもっともアクティビティ の)茼い外部のロビー管閌である。

(no. 35) 人の流れをつくる/2 流れが発生 $/ 1$ 人の流れの誘引/1 人びとを誘い込む $/ 1$ 流れが集まるところ/1 人の流狆の絬節焦/1 流れのバランスを整える/1

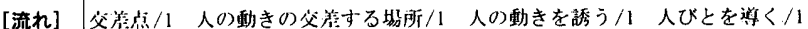

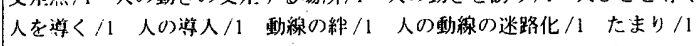
溜り $/ 1$ 湤み $/ 1$ よどみ 11 溜まり場 $/ 2$

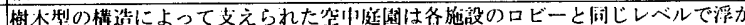

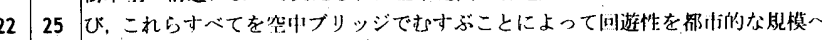

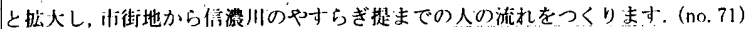
集い/5 集う/4 つどい/2 集まり/2 あつまり/1 集命 $/ 1$ 怜い/3

[出会い] 集い/5

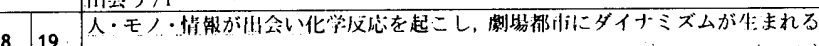

1 父流 $/ 6$ 父感 $/ 1$ 爹发 $/ 1$ 父歓 $/ 1$ 税睦 $/ 1$ 触れ命い $/ 2$ ふれあい/1

[交流] 話り合う $/ 2$ 視覚父流 $/ 1$ 視線が父篗し命う $/ 1$ コミュニケーション $/ 3$

コミュニケイトー1 コミュニティ/5

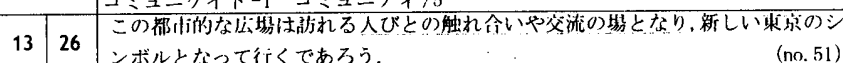

[賬わい] 眼わい/10 にぎわい/1:活父 $/ 2$ 活性化 $/ 1$

4 4 14 「大階段」には、いろいろな眼わいを誘うという壳味がある。

イベント / 7 イベント㕕暘 $/ 3$ イベントブラザ $/ 2$ イベントスベース /

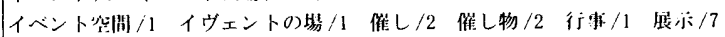

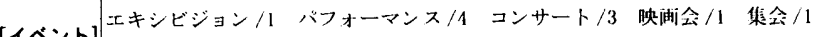

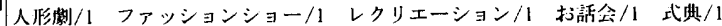

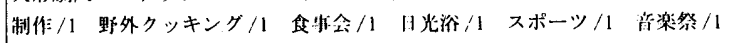

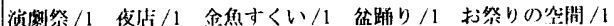

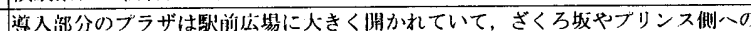

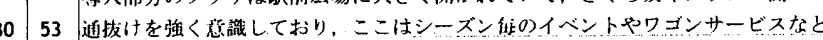

に利州されることをア定している。

(no. 31)

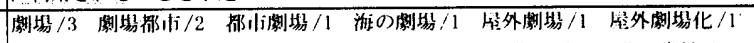

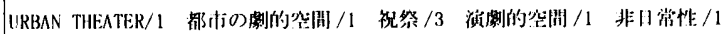

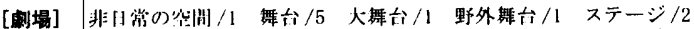

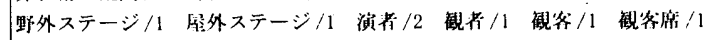

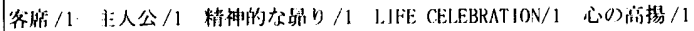
罗る見られる/1

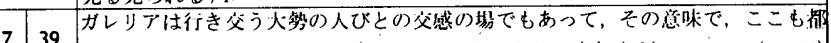

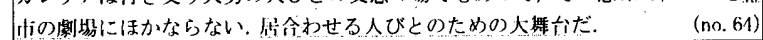

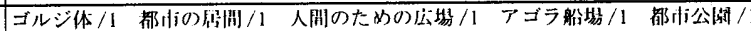

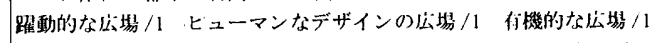

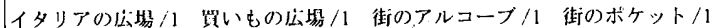

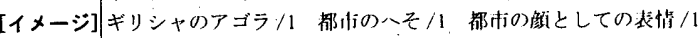

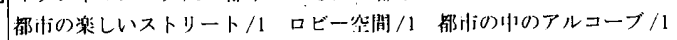

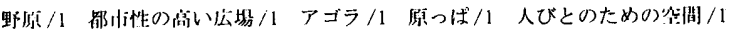

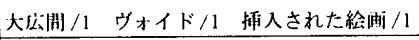

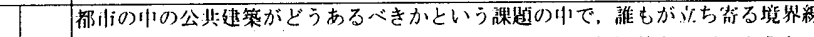

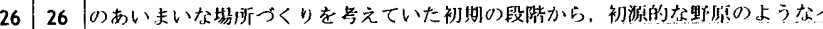
メージがあった (no. 44)

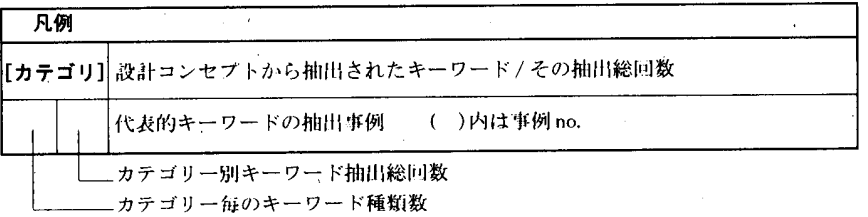




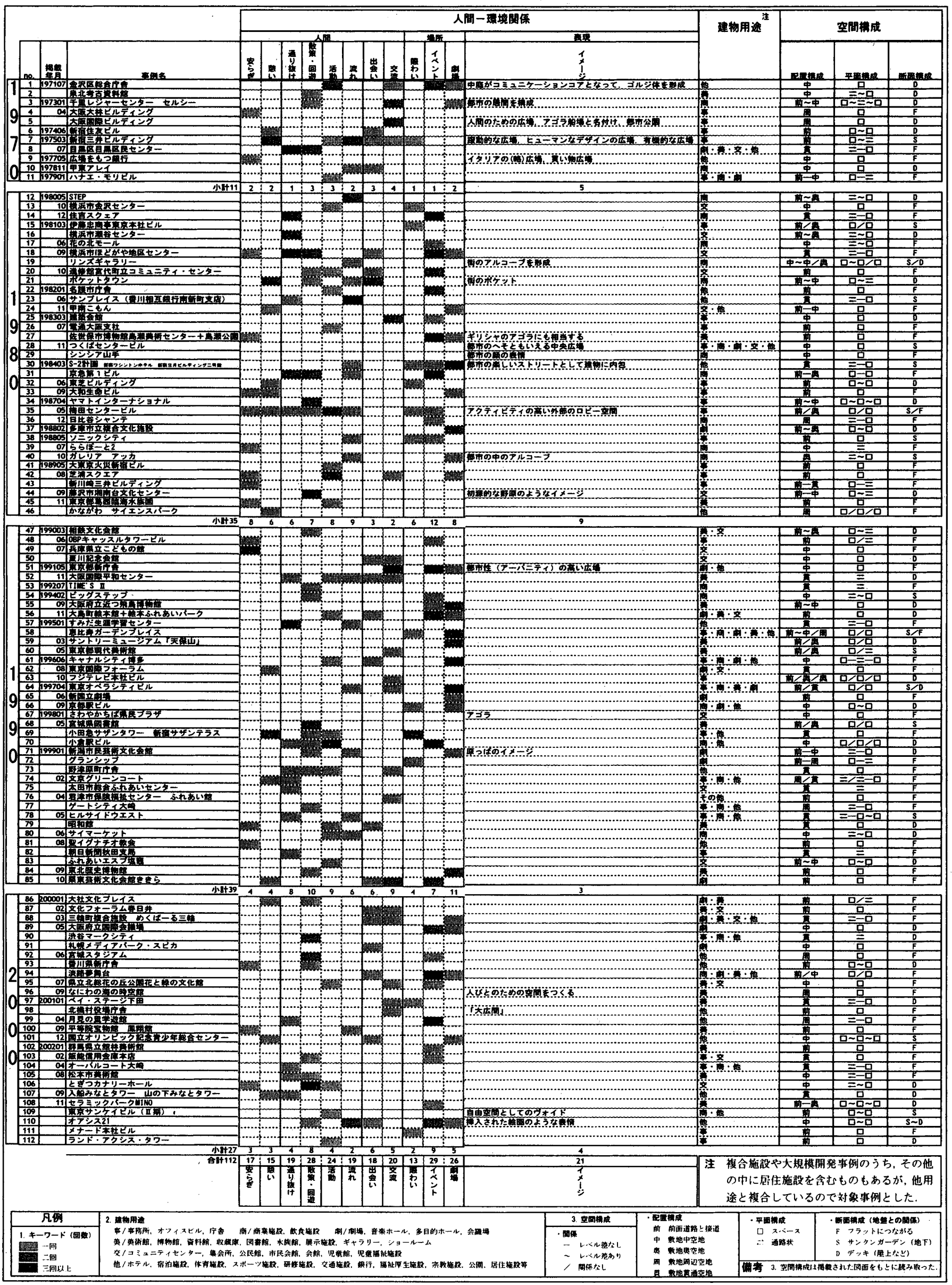

図 3 対象事例一覧 

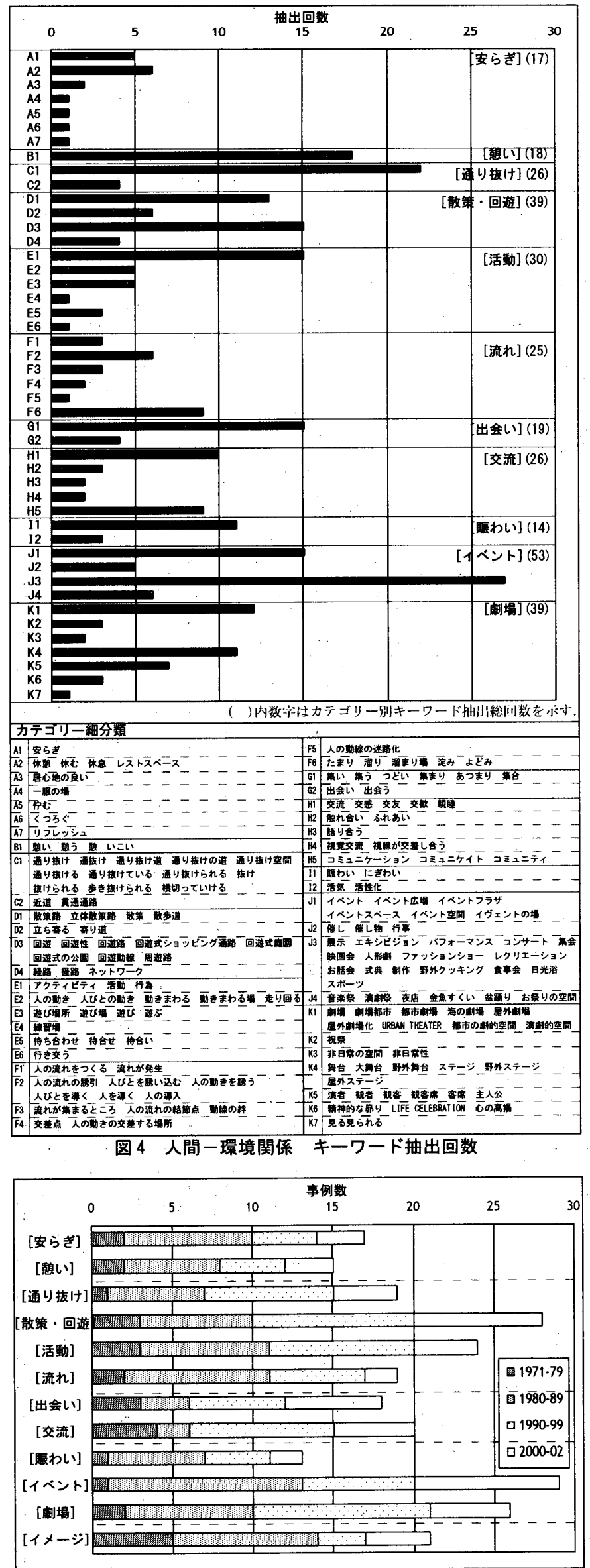

图 5 人間－環境関係 .年代別抽出頻度

\section{3. 設計コンセプトにみる人間一環境関係の分類}

設計コンセプトの中から抽出したキーワードを $\mathrm{KJ}$ 法的 ${ }^{(10)} に$ 分類し た，具体的には，【人間】の行為・状態に関する項目として，利用者の リラックスした状態を意図した[安らぎ][䕀い]，建物に気軽に立ち奇 ることを意図した[通り抜け，敷地内で動きまわる行為を意図した， [散策・回遊] [活動]，敷地外をも含んだ人の流れをつくり出そうとす る[流れ], 他者と新しい関係を持つことを意図した[出会い], 他者と の関係を持つことを意図した[交流]，また【場所】に関する項目とし て，場所で利用者が賑わう様子を意図した[賬わい，場所での催し物 やイベントを表寸 [イベント]，場所が劇場のイメージとなるよう意図 した[劇場]，【表現】に関する項目として，場所のイメージを一言で表 現した[イメージ]の計 12 個に分類することができた（表1)：これら力 テゴリーのうち, 最も多く抽出されたのは, [イベント] (53回), ついで [劇場] [散策・回遊] (39回), [活動] (30回) となった。ささらに, 同一力 テゴリー内で類似したキーワードをまとめてみると（図4), 展示など 各種イベント利用を意図したもの [J3]が最も多く(27回)，ついで通り 抜ける [C1] (22回)，憩い[B1] (18回) となっている.また，同一表現で 最も多く抽出されたキーワードは, 憙い（12回），ついで「アクティ ビティ」(11回)，「賑わい（10回）となっており，この3つのキーワー ドがよく用いられる単語であるといえる.

\section{4. 設計コンセプトにみる人間一環境関係の分析}

\section{1 曲出頻度}

全 112 事例中, 最も抽出頻度が多いのは, [イベント]で, 29 事例, つ いで, [散策・回遊] 28 事例で共に $1 / 4$ 以上の事例で抽出された．以下， [劇場] で26事例, [活動]24事例, [イメージ]21事例, [交流]20事例, [通 り抜け] [流れ] 19 事例, [出会い] 18 事例, [安らぎ] 17 事例, [息い] 15 事 例，[賬わい]13事例となっている（図 5).

\section{2 時代的変遷（以下（）内数字は事例数を示す）}

各事例においてどの分類用語が抽出されたかを年代毎に分析した結 果（図 3)，以下のような傾向を読み取ることができる（図 5, 表 2). i ) 1970 年代 (11)は，強いていえば[イメージ](5)が多い, ii ) 1980 年代 (35) は, [イベント] (12), [流れ] [イメージ] (9),

[安らぎ][活動][劇場] (8),

iii) 1990 年代 (39) は, [劇場] (11), [散策・回遊] (10), [活動] [交流] (9), [通り抜け] (8)，

iv ) 2000 年以降 (27) は, [イベント] (9), [散策・回遊] (8),

さらに，各キーワード毎に見ていくと，

v ) [安らぎ $]$ は 1980 年代に多い $(8 / 17)$,

vi）[散策・回遊]は 1990 年代以降に多い $(18 / 28)$,

vii）[活動] [劇場]は 1980 年代 90 年代に多い(17/24) (19/26),

viii）[流れ]は 1980 年代に多い (9/19)，

ix) [交流]は 1990 年代に多い $(9 / 20)$,

表 2 人間一環境関係 年代別傾向

\begin{tabular}{|c|c|c|c|c|c|c|c|c|}
\hline カテゴリー & \multicolumn{2}{|c|}{$1971-79$} & \multicolumn{2}{|c|}{$1980-89$} & \multicolumn{2}{|c|}{$1990-99$} & \multicolumn{2}{|c|}{$2000-02$} \\
\hline 安らぎ & 2 & 6.9 & 8 & 9.5 & 4 & 4.9 & & 5.5 \\
\hline 款い & 2 & 6.9 & 6 & 7.1 & 4 & 4.9 & 3 & 5.5 \\
\hline 通り报け & 1 & 3.4 & 6 & 7.1 & $8:$ & 9.9 & 4 & 7.3 \\
\hline 散策 - 回遊 & 3 & 103 & 7 & 8.3 & 10 & 123 & 8 & 14.5 \\
\hline 活動 & 3 & 10.3 & 8 & 9.5 & 9 & 111 & 4 & 7.3 \\
\hline 流れ & 2 & 6.9 & 9 & 107 & 6 & 7.4 & 2 & 3.6 \\
\hline 出会い & 3 & 103 & 3 & 3.6 & 6 & 7.4 & 6 & 109 \\
\hline 交流 & 4 & 13.8 & 2 & 2.4 & 9 & 11,1 & 5 & 9.1 \\
\hline 賑わい & 1 & 3.4 & 6 & 7.1 & 4 & 4.9 & 2 & 3.6 \\
\hline イベント & 1 & 3.4 & 12 & 143 & 7 & 8.6 & 9 & 16.4 \\
\hline 剽場 & 2 & 6.9 & 8 & 9.5 & 11 & 136 & 5 & 9.1 \\
\hline イメーシ & 5 & 172 & 9 & 107 & 3 & 3.7 & 4 & 7.3 \\
\hline Bt+ & 29 & 100.0 & 84 & 100.0 & 81 & 100.0 & 55 & 100.0 \\
\hline
\end{tabular}

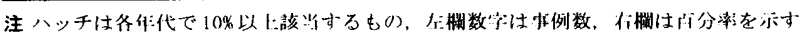




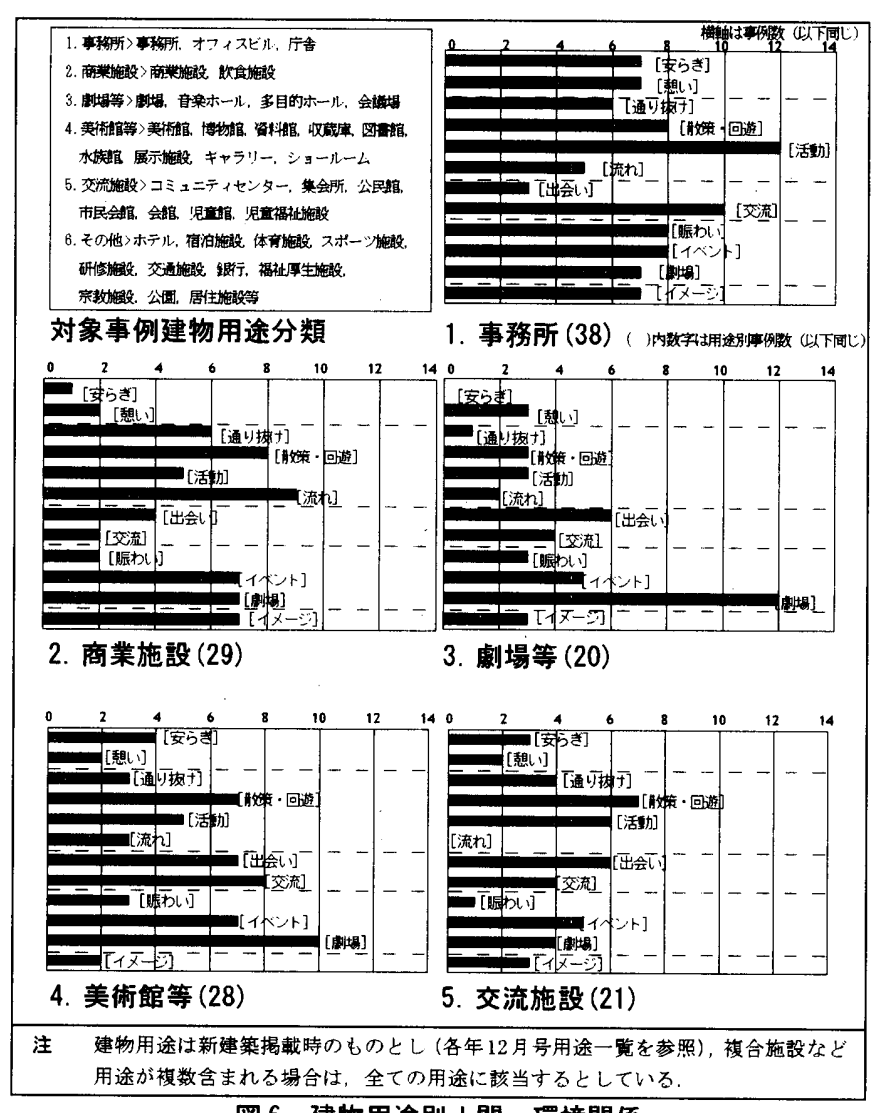

图 6 建物用途別人間一環境関係

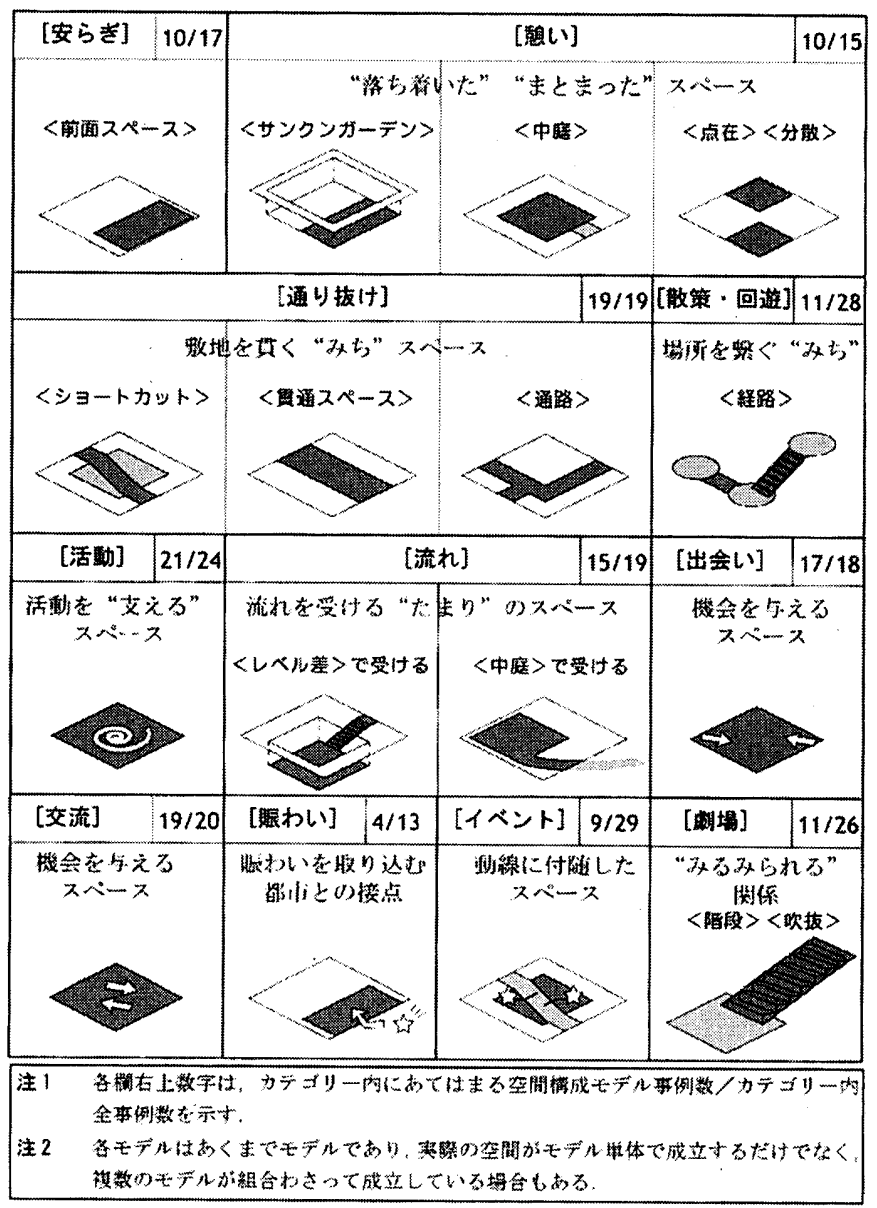

図 7 人間一環境関係と空間構成 x ) [イベント]は 1980 年代上 2000 年以降に多い (12/29) (9/29),

xi）[イメージ]は 1970 年代 80 年代に多い (14/21).

といった傾向を読み取ることができる.

以上のことから設計コンセプトにみる人間－環境関倸の時代的変遷 を大まかにまとめると，1970年代にはさまざまな議論がなされ，1980 年代以降, [イベント][劇場]といった都市に賑わいをもたらそうとする 流れ之, [通り抜け][散策・回遊][流れ]といった人びとのアクティビ ティを操作しようとする流れにわかれ，さらに1990年代にはいると， それらに加え, [交流]という他者も含めた関係を築いてもらおうとする 流れが生まれたということができる。

\section{3 建物用途}

対象事例をパブリックオープンスペースに付随する建物用途別に分 類すると，(図 6) のようになる. 建物用途毎にカテゴリーの傾向をみ る上，1. 事務所 (38)では, 他用途に比べ偏った傾向はみられないが, [活動] (12)，[交流] (10)などが比較的多くみられる。2. 商業施設 (29) は, [流れ] (9)，[散策·回遊] (8)，[イベント][劇場] (7)が多くみられる. このことは敷地内に人を導き, 動きまわることにより, 施設全体を活 気あるものにし，集客力を向上させたいという事業主側の意図が反映 されていると思われる．3．劇場等(20)は，12 事例が[劇場]のカテゴ リーに該当し，建物用途に関するキーワードが多く用いられている. 4. 美術館等 (28)も3. 劇場等同様 [劇場] (10)が多くみられるが, [交流] (8)，[散策・回遊] [出会い][イベント] (7)なども多くみられる.5. 交流 施設 (21)は, [散策・回遊] (7), [活動] [出会い] (6)が比較的多い.

以上をま之める上, パブリックオープンスペースでの人間の行為, 利用と建物用途の関連が希薄な, 1. 事務所, 4. 美術館等, 5 . 交流施設 では，さまざまな設計コンセプトが用いられる傾向にあり，関連が強 い, 2. 商業施設, 3. 劇場等は, ある特定の限られた設計コンセプトが 用いられる傾向にある。

\section{4 空間構成}

次に, 対象事例の空間構成を, 配置構成, 平面構成, 断面構成につ いてそれぞれ分類し，カテゴリ一毎に傾向をみる上，周辺環境や建物 規模による影響も考えられるが，いくつかの傾向がみられた（図 7). [䕀い]については，キーワードの種類はあまり多様ではないが，空間 構成のバリエーションは比較的多い。

しかし，全体的に[通り抜け][散策・回遊］[流れ]以外は，人間一環 境関保に対态した空間構成はあまりみられず, [交流] [賬わい]などにつ いては目標とした人間一㻴境関係を実現する手法はそしいといえる.

\section{5. まとめ}

新建築に掲載された事例というある限られた範囲内ではあるが，パ ブリックオープンスペースの設計時のコンセプトの中に抽出された人 間一環境関係にいくつかの傾向を読み取ることができた．

それらを設計者と利用者の関保からまとめると, [安らぎ][咊い] いった利用する人びと自身の心理，感情を表す行為を意図したもの， [通り抜け][散策・回遊] [活動] [流れ] といった設計者がその場を利用 する人びとに対してこうしてほしいというような意図を含んだ人間の 行為を制御しようとするもの, [出会い] [交流] といった設計者がその場 を利用する人びとを積極的に関係づけようとした擬似的なもの，賑わ い][イベント][劇場]上いった利用する人びとの日常とは異なったその 場所の状態を意図したもの, [イメージ]のように設計者固有の言語で場 所の状態を表現しようとするものの 5 種類に分類できる（図 8).

それらの時代的変遷は, 1970年代は[散策・回遊] [活動] [出会い] [交 流] [イメージ]などで比較的多くのキーワードが用いられ，1980年代以 降, [イベント][劇場]や[散策・回遊][流れ]といった言語が用いられる ようになる.さらに 90 年代以降, それらに[通り抜け][出会い][交流] 


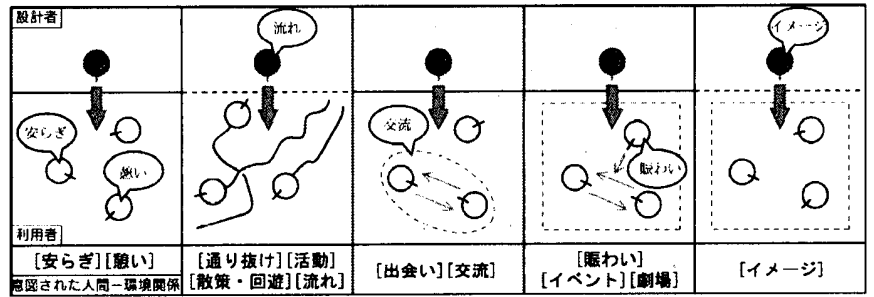

图 8 設計者と利用者の関係からみた人間一噮境関係
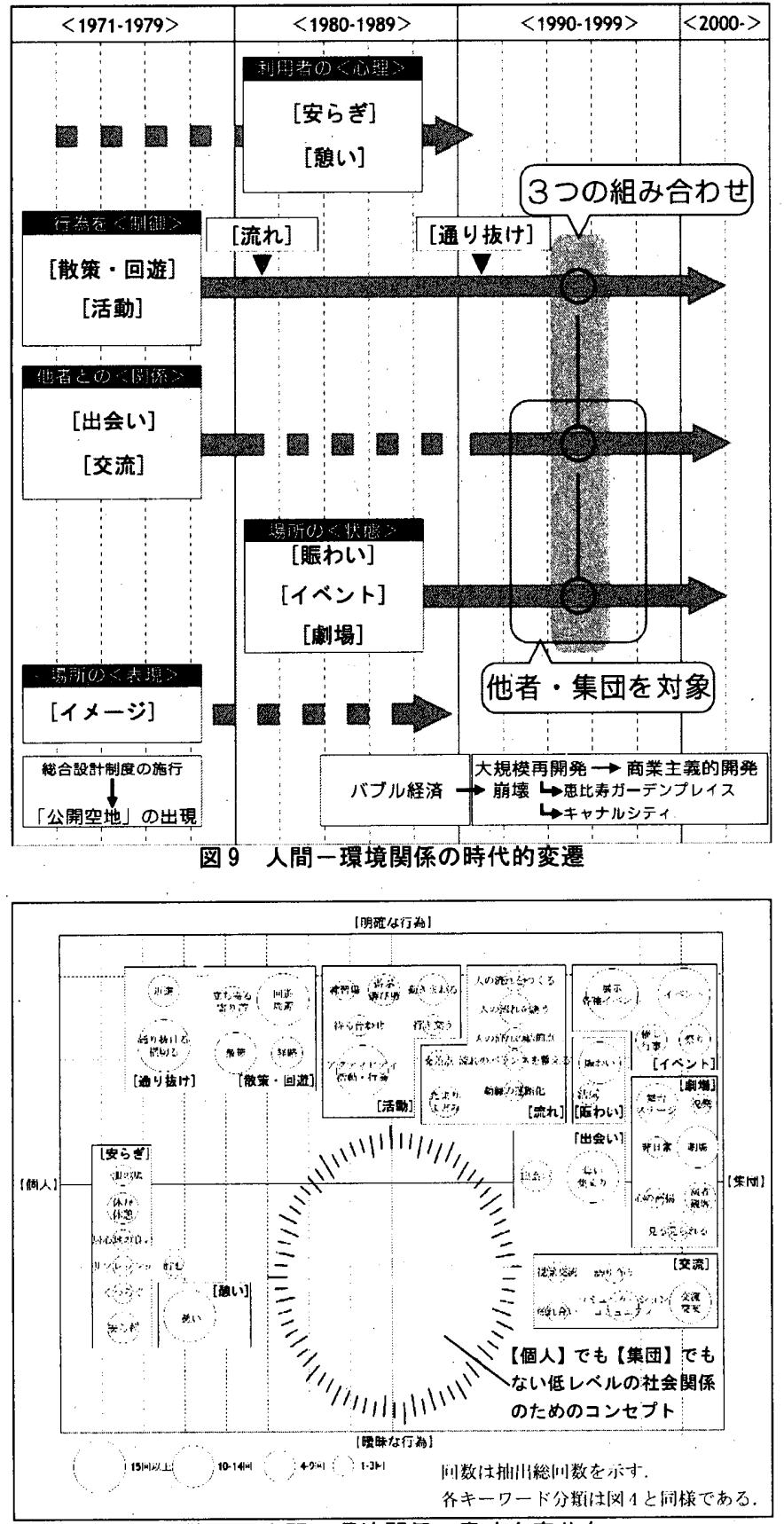

図 10 人間一環境関係の意味内容分布

\section{参考文献}

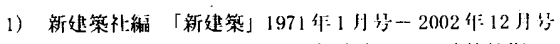

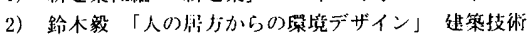

1993. 07, 09, 1994. 02, 04, 06, 08, 10, 12, 1995. 02, 04, 06, 08, 12

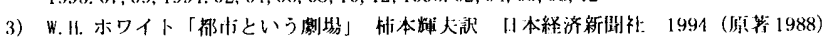

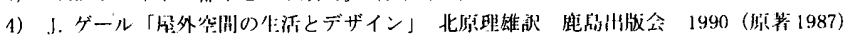

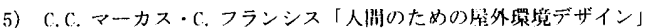

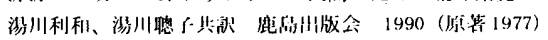

が加わり，2000年以後もこの傾向は続いているように思われる (図9).

こうした流れの中で, 全体として[安らぎ][䉒い]以外は人間の積極 的な行動に関わるものが多く, 人びとを関保づけ，擬似的なュミュニ ティを発生させるような, その場で行われる行為や関係を『規定』『誘 発』することを意図したものが多い，逆に「ひとり」でも「都市」を 感じられることを意図したコンセプト，例えば，「孤独性を享受する」 (11)というような対象を集団としない考え方やにひとりで何もせずにた だ居られる」といった暧昧な行為 ${ }^{(12)}$ を意図したものなどは, 今回の データからはあまり得られなかった（図10)。このことは, これまで計 画されてきたパブリックオープンスペースの目標像が, 社会の中の集 団を相手の明確な行為を目標として計画されてきたと読奴ることも 可能である.

今後, 都市の中でさまざまな人びとが「ただ居られる」ようなパブ リックオープンスペースのためには, 知覚・認知などもっと低レベル の社会関倸 ${ }^{(13)}$ のためのコンセプトも必要ではないだろうか.さらに, そのような低レベルの社会関係をつくりだすための建筑ボキャブラ

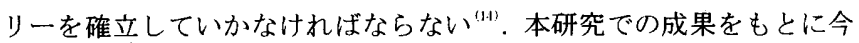
後, いくつかの代表的な事例について実態調查を行い, パブリック オープンスペースに対する新たな知見を得たい.

\section{注釈}

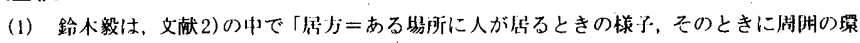

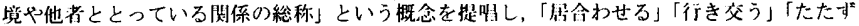

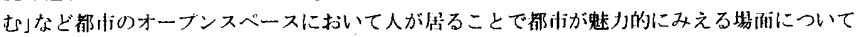
速截している。

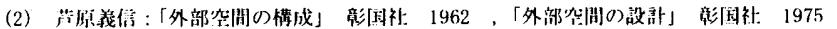

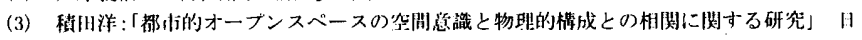

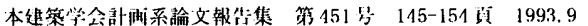

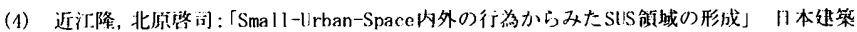

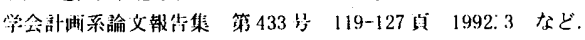

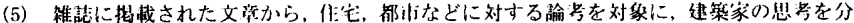

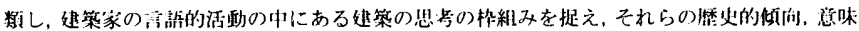

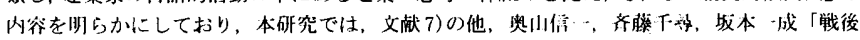

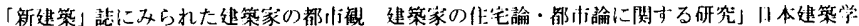
会部间系諭文银等集第 $414 \%$ '

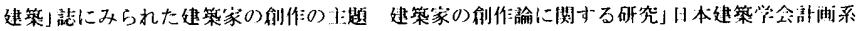

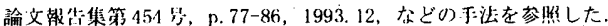

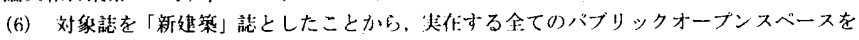

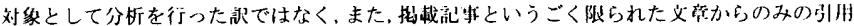

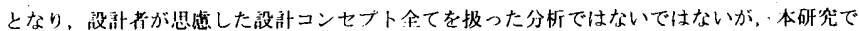

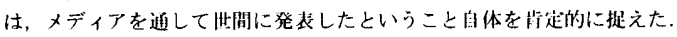

（7）総命設部制传が施行されたのが1971和であるため，対象を1971件以後とした。

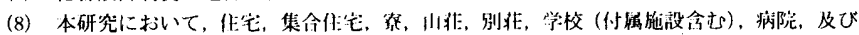

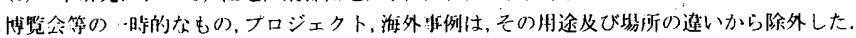

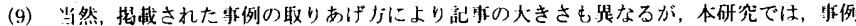

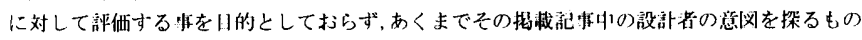

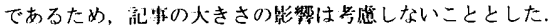

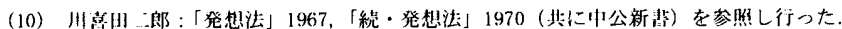

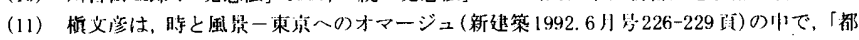

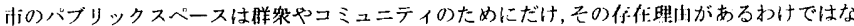

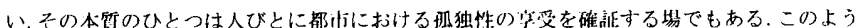

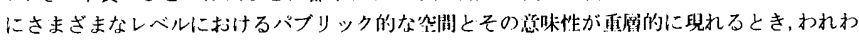

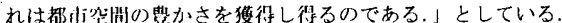

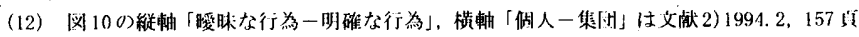
の四3をもとに俳成した。

(13）例えば，」ダールがいう「他の段階のふれあいが生まれる川発点の问能性」としての

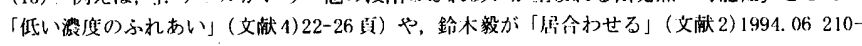

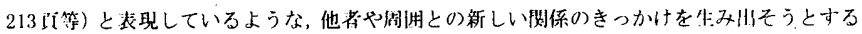
コンセブトが必要であると思われる。

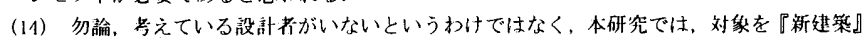

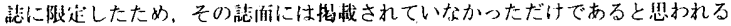

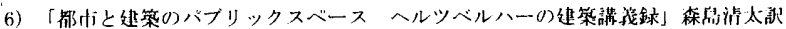

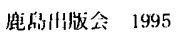

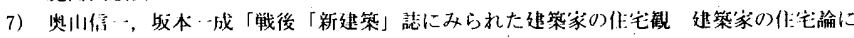

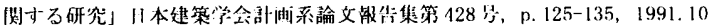

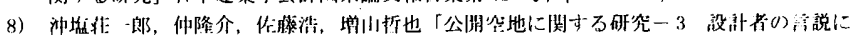

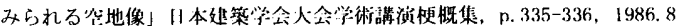

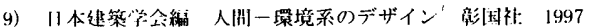

